\title{
REVIEW:
}

\section{GREEN ANALYTICAL CHEMISTRY: PEMANFAATAN SUPERCRITICAL FLUID EXTRACTION (SFE) DAN MICROWAVE-ASSISTED EXTRACTION (MAE) SEBAGAI METODE EKSTRAKSI SENYAWA DITERPENA PADA MINYAK BIJI KOPI SHANGRAI}

\author{
Rinawati $^{1}$, Gesa Gustami Pangesti ${ }^{1}$, Ni Luh Gede Ratna Juliasih ${ }^{1}$ \\ ${ }^{1}$ Jurusan Kimia FMIPA Universitas Lampung, J1 Sumantri Brojonegoro No. 1 \\ Bandar Lampung, 35145 \\ rinawati@fmipa.unila.ac.id
}

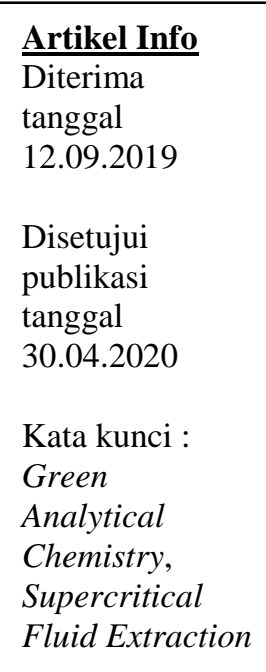

ABSTRAK

Green Analytical Chemistry (GAC) telah menjadi konsep utama dalam menciptakan metode yang berkelanjutan untuk mengatasi tantangan analisis senyawa yang memadukan prinsip cerdas, ramah lingkungan, dan murah. Selama ini ekstraksi minyak dari kopi hijau masih menggunakan metode lama seperti pressing dan soxhletasi yang membutuhkan banyak pelarut dan tidak efisien dari segi waktu sehingga memiliki potensi pencemaran bagi lingkungan dan menguapnya analit bersama pelarut. Metode ekstraksi Supercritical Fluid Extraction (SFE) dan Microwave-Assisted Extraction (MAE) merupakan metode ekstraksi modern yang mengacu pada konsep GAC karena penggunaan energi dan pelarut yang diminimalisir serta waktu dan biaya yang lebih efektif sehingga bersifat lebih ramah lingkungan. Kedua jenis metode ini telah diterapkan dalam mengekstraksi senyawa diterpena pada minyak kopi hijau Arabika yang berasal dari Sao Paulo, Brazil.

\section{ABSTRACT}

Green Analytical Chemistry (GAC) has become the major concept in creating sustainable methods to overcome the challenges of compound analysis that combine smart, environmentally friendly and inexpensive principles. So far, the extraction of oil from green coffee still uses old methods such as pressing and soxhletation which require a lot of solvents and are not efficient for the timing so they have the potential to pollute the environment and evaporate the analyte along with the solvent. Supercritical Fluid Extraction (SFE) and Microwave-Assisted Extraction (MAE) are modern extraction methods that refer to the GAC concept because of the minimized use of energy and solvents and more effective in time and costs so these methods are more environmentally friendly. Both types of methods have been applied in extracting diterpenes compound in Arabica green coffee oil from Sao Paulo, Brazil.

\section{PENDAHULUAN}

Semakin meningkatnya jumlah penduduk di seluruh dunia seiring dengan perkembangan jenis aktivitas yang pesat memberikan dampak yang luar biasa terhadap

doi: http://dx.doi.org/10.23960/aec.v5.i1.2020.p24-33

Anal.Environ.Chem. 
perubahan dunia. Hal ini memicu kebutuhan mendesak akan kesinambungan semua aktivitas manusia dan mempercepat evolusi dari paradigma kimia ke paradigma lingkungan. Efek samping terhadap lingkungan yang disebabkan kegiatan manusia terutama yang melibatkan senyawa-senyawa kimia harus mulai dipertimbangkan secara serius. Green Chemistry (Kimia Hijau) dan Green Analytical Chemistry (Kimia Analitik Hijau) berevolusi dari bidang akademik ke dunia nyata, menjadi sebuah kegiatan penelitian luar biasa untuk analisis berbagai jenis sampel berbasis Kimia Analitik Hijau (Anwar, 2015).

Saat ini para peneliti percaya bahwa Kimia Analitik Hijau akan sangat berguna di tahun-tahun mendatang. Penerapan yang cepat dan murah, ramah lingkungan, serta prosedur yang aman dalam analisis lingkungan, klinis dan makanan akan meningkatkan kualitas hidup di negara-negara berkembang. Hal ini menunjukkan bahwa Kimia Analitik Hijau telah menjadi alat utama untuk berpindah dari paradigma kimia ke paradigma ekologi dan menciptakan alat yang berkelanjutan untuk mengatasi tantangan dalam meningkatnya permintaan analisis senyawa yang memadukan prinsip cerdas, ramah lingkungan, dan murah (Namiesnik, 2000).

Konsep Kimia Hijau dengan 12 prinsip dasarnya telah diadaptasi untuk mendefinisikan kimia analitik hijau meliputi: (1) teknik analitik langsung harus diterapkan untuk menghindari perlakuan sampel, (2) mengutamakan ukuran sampel minimal dan jumlah sampel minimal, (3) pengukuran in situ harus dilakukan, (4) integrasi proses analitik dan operasi menghemat energi dan mengurangi penggunaan reagen, (5) otomatis dan metode miniatur harus dipilih, (6) derivasi harus dihindari, (7) generasi limbah analitik dalam jumlah besar harus dihindari dan pengelolaan limbah analitik yang tepat harus disediakan, (8) multianalit atau metode multiparameter lebih disukai dibandingkan metode yang menggunakan satu analit di satu waktu, (9) penggunaan energi harus diminimalkan, (10) reagen diperoleh dari sumber terbarukan lebih disukai, (11) reagen beracun harus dihilangkan atau diganti dan (12) keselamatan operator harus ditingkatkan.

Dari serangkaian prosedur dalam menganalisis senyawa kimia, teknik preparasi merupakan teknik awal yang sangat kritis. Jika pada tahap kita tidak berhasil untuk memisahkan senyawa yang diinginkan, maka pada tahap selanjutnya akan sangat sulit untuk mengidentifikasi senyawa yang ditargetkan. Salah satu teknik preparasi yang sering digunakan adalah ekstraksi. Ekstraksi adalah proses pemisahan suatu zat berdasarkan perbedaan kelarutannya terhadap dua

doi: http://dx.doi.org/10.23960/aec.v5.i1.2020.p24-33 Anal.Environ.Chem. 
pelarut berbeda yang yang saling campur. Ekstraksi konvensional seperti soxhletasi, refluks dan maserasi, umumnya memerlukan waktu yang sangat lama dan masih menggunakan pelarut atau bahan kimia beracun, yang dalam hal ini tidak sesuai dengan konsep Kimia Analitik Hijau. Oleh sebab itu, dewasa ini dikembangkan metode ekstraksi modern yang memenuhi kriteria dari konsep Kimia Hijau. Konsep ekstraksi modern tersebut banyak digunakan dalam analisis sampel lingkungan (Rinawati, 2017) tetapi juga dapat digunakan dalam analisis senyawa pada minuman seperti kopi.

Kopi secara tradisional digunakan sebagai minuman, tetapi belakangan ini, minyak biji kopi hijau sangrai telah banyak dikembangkan untuk keperluan lain seperti kosmetik, obat, antioksidan dan lain-lain secara komersial. Biji kopi hijau sangrai mengandung 7-17\% lemak yang terdiri dari triasilgliserol (75\%) dan asam lemak bebas, mirip dengan komposisi minyak tanaman lainnya (Ferrari et al., 2010). Fraksi yang tidak dapat mengalami penyabunan dari minyak biji kopi hijau terdiri dari sterol, fosfatida, diterpena, seramida dan komponen kecil lainnya. Dua diterpen utama diamati dalam kopi adalah cafestol dan kahweol (Speer and Kölling-Speer, 2006). Aktivitas biologis kedua zat itu pertama kali dilaporkan oleh Lam et al. (1982), yang menyatakan bahwa cafestol dan kahweol palmitat meningkatkan aktivitas glutathione S-transferase (GST) di hati dan usus halus tikus. Selanjutnya, dalam model hewan, diterpena ini telah terbukti menghasilkan efek biologis seperti antikanker dan sifat kemopreventif (Boekschoten et al., 2004).

Di industri, minyak biji kopi diperoleh dengan menekan biji dengan expeller. Namun, dalam beberapa tahun terakhir, teknik baru berbasis Kimia Hijau telah dievaluasi pada skala laboratorium untuk meningkatkan fraksi senyawa yang diminati dan untuk meningkatkan hasil proses. Beberapa teknik baru tersebut meliputi ekstraksi cairan superkritis (SFE), ekstraksi cair bertekanan (PLE), ekstraksi berbantuan gelombang mikro (MAE), dan ekstraksi mikro fase padat (SPME). Teknik-teknik ini telah digunakan untuk mengekstraksi komponen kecil (atau utama) dari sampel makanan dan pertanian.

Dalam tulisan ini akan dijabarkan beberapa hasil penelitian mengenai penggunaan metode Supercritical Fluid Extraction (SFE) dan Microwave-Assisted Extraction (MAE) dalam

doi: http://dx.doi.org/10.23960/aec.v5.i1.2020.p24-33

Anal.Environ.Chem. 
penentuan senyawa diterpena pada minyak biji kopi hijau yang mengacu pada konsep Kimia Analitik Hijau.

\section{SUPERCRITICAL FLUID EXTRACTION (SFE)}

Fluida superkritis adalah unsur atau senyawa di atas tekanan dan suhu kritisnya, seperti terlihat pada Gambar 1. Ketika kombinasi temperatur dan tekanan suatu zat berada dalam kesetimbangan termodinamika antara gas, cairan dan padatan maka disebut titik tripel suatu zat. Daerah di atas tekanan dan temperatur kritis disebut fluida superkritis. Karakteristik seperti gas dan melarutkan sesuatu seperti cairan membuat fluida superkritis ini menjadi unik. Secara umum diffusivitas dan viskositas fluida superkritis mendekati gas, akan tetapi densitasnya mendekati cairan, sehingga hal tersebut sangat bermanfaat untuk transfer massa.

Beberapa fluida superkritis (SF) dapat digunakan sebagai pelarut ekstraksi dalam SFE, tetapi hanya $\mathrm{CO}_{2}$ yang akan dibahas di sini karena toksisitasnya yang rendah, suhu dan tekanan kritis yang rendah (Tc dari $31^{\circ} \mathrm{C}$ dan Pc dari 72 bar), dan penerapan yang luas.Salah satu fluida superkritis yang banyak digunakan dalam ekstraksi adalah karbondioksida $\left(\mathrm{CO}_{2}\right)($ Pourmortazavi et al., 2014).

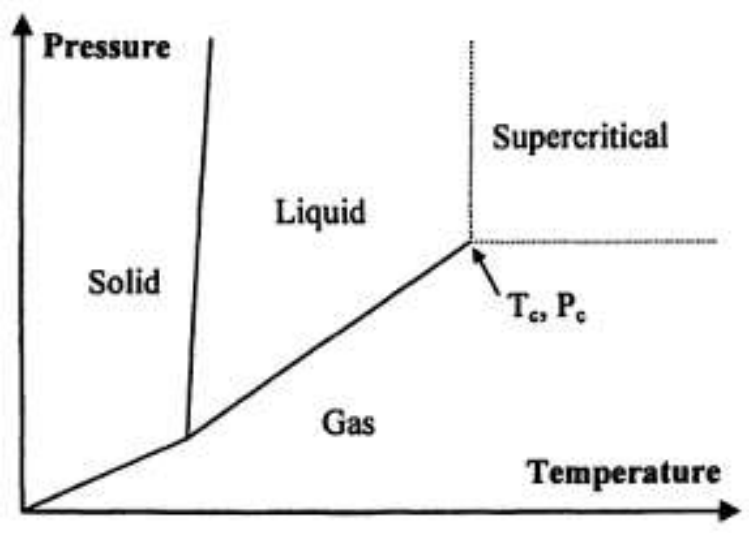

Gambar 1. Diagram Fasa

SC- $\mathrm{CO}_{2}$ menarik sebagai media ekstraksi karena difusivitas tinggi dikombinasikan dengan kekuatan pelarut yang tinggi (dan mudah dirancang). Keuntungan lain dari SC- $\mathrm{CO}_{2}$ adalah bebentuk gas pada suhu kamar dan tekanan ruang, yang membuat pemulihan produk (atau

doi: http://dx.doi.org/10.23960/aec.v5.i1.2020.p24-33 Anal.Environ.Chem. 
analit) cukup sederhana. Terlebih lagi, $\mathrm{CO}_{2}$ dapat dengan mudah didaur ulang karena zat terlarut dalam $\mathrm{SC}-\mathrm{CO}_{2}$ akan mengendap pada saat depressurisasi.

SFE dilakukan dengan memompa SF melalui bejana yang diisi dengan sampel, dan selanjutnya mengurangi tekanan SF untuk pengumpulan komponen yang diekstraksi. Oleh karena itu, instrumen SF terdiri dari satu atau dua pompa tekanan tinggi untuk pengiriman SF dan diperlukan juga kosolvent polar seperti etanol, bejana bertekanan tinggi untuk menampung sampel, pembatas dan perangkat pengumpul (misalnya wadah kosong atau tabung gelas yang mengandung pelarut pengumpul). Wadah sampel ditempatkan dalam oven untuk mengontrol suhu ekstraksi. Ilustrasi dari susunan instrumen SFE dapat dilihat pada Gambar 2.

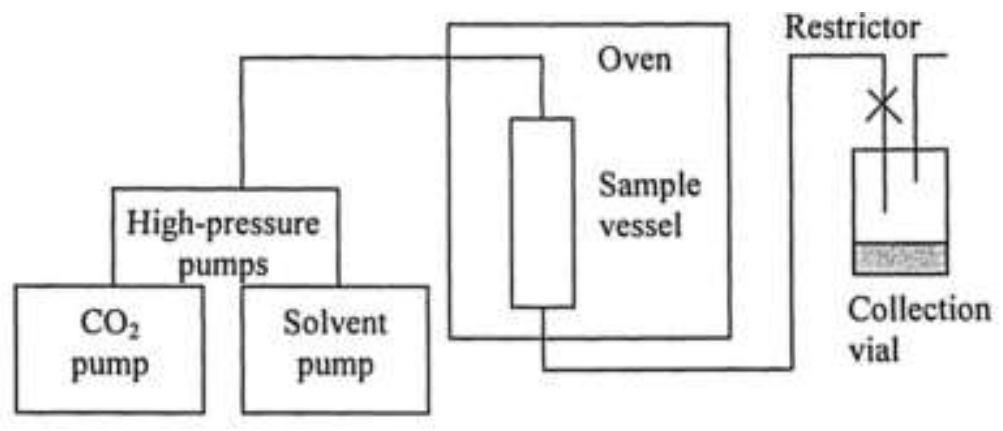

Gambar 2. Ilustrasi Instrumen SFE

Pengembangan metode dalam SFE tidak begitu sederhana karena beberapa parameter harus dioptimalkan, termasuk suhu dan tekanan SF, waktu ekstraksi, laju aliran, penambahan kosolvent (jenis pelarut dan jumlah) dan mode pengumpulan (misalnya dalam pelarut, dalam bejana kosong atau pada perangkap fase padat). Lebih lanjut, metode-metode ini pada umumnya bergantung pada matriks, yaitu metode yang dikembangkan hanya untuk molekul target tertentu yang tidak dapat langsung diterapkan ke molekul sampel jenis lainnya.

SFE telah digunakan di industri industri pengolahan tanaman seperti John Haas, pabrik ekstraksi hop di Yakima, Washington, pabrik ekstraksi minyak biji artech berry di Torneo, Finlandia, pabrik ekstraksi kulit birch Natur North Technologies di Duluth, Minnesota, dan beberapa pabrik tanpa kafein di Amerika Serikat dan Jerman. Dalam hal aplikasi penelitian, SFE telah digunakan untuk ekstraksi sampel makanan, pertanian dan tanaman dengan publikasi yang terus meningkat (Turner, 2006). SFE juga telah sukses digunakan untuk preparasi dalam

doi: http://dx.doi.org/10.23960/aec.v5.i1.2020.p24-33

Anal.Environ.Chem. 
analisis sampel lingkungan, bahkan telah diintegrasikan dengan instrumentasi lain untuk melakukan analisis simultan (Juliasih et al, 2015).

Oliveira et al. (2014) telah menggunakan teknik SFE untuk mendapatkan ekstrak minyak dari kopi hijau sangrai (Coffea arabica, cv. Yellow Catuaí) yang diperkaya dengan senyawa diterpen, cafestol dan kahweol. Untuk mendapatkan minyak kopi hijau yang mengandung diterpena yang berguna untuk obat-obatan, desain rotasi komposit sentral (CCRD) digunakan untuk mengoptimalkan proses ekstraksi. Dalam penelitian tersebut dilakukan variasi suhu dan tekanan untuk memperoleh kondisi yang optimum. Meski pun suhu dan tekanan tidak memiliki pengaruh yang berbeda nyata, namun secara individual teramati konsentrasi diterpen yang tinggi pada suhu yang tinggi. Kadar minyak biji kopi hijau sangrai meningkat jika suhu dinaikkan. Hasil ekstraksi SFE optimum diperoleh pada suhu $70^{\circ} \mathrm{C}$ dan tekanan 200-300 bar menunjukkan hasil yang lebih tinggi sekitar 85\% untuk kafestol dan $80 \%$ untuk kahweol dibandingkan dengan cara konvensional menggunakan teknik expeller. Analisis dan kuantifikasi diterpen dilakukan dengan menggunakan instrumen kromatografi gas-spektrometri massa (GCMS) menunjukkan bahwa minyak kopi hijau dari SFE mengandung senyawa cafestol 50,2 dan kandungan kahweol 63,8 g/kg minyak kopi hijau, sedangkan pada sampel yang sama diperoleh senyawa cafestol 7,5 dan kandungan kahweol 12,8 g/kg minyak kopi hijau.

Minyak kopi hijau dari SFE juga mengandung asam lemak, seperti asam palmitat (9,3 mg MAE/g minyak kopi hijau), asam linoleat tak jenuh ganda ( $\omega-6 ; 11 \mathrm{mg} \mathrm{MAE/g} \mathrm{minyak} \mathrm{kopi}$ hijau) dan asam oleat ( $\omega-9 ; 3,8 \mathrm{mg}$ MAE/g minyak kopi hijau). Sifat fisik untuk minyak kopi hijau yang dihasilkan dari SFE dan tekanan konvensional menunjukkan kepadatan dan viskositas menurun dipengaruhi suhu.

\section{MICROWAVE-ASSISTED EXTRACTION (MAE)}

Ekstraksi dibantu dengan Microwave (MAE) juga merupakan teknik ekstraksi berdasarkan pemanasan pelarut organik. Prinsipnya kira-kira bahwa sampel dan pelarut yang tepat (atau campuran pelarut) dimasukkan ke dalam bejana, yang kemudian diberi tekanan dan dipanaskan oleh gelombang mikro. Setelah 5 hingga 20 menit, biasanya ekstraksi selesai, dan bejana dibiarkan dingin sebelum mengeluarkan sampel / campuran pelarut. Pelarut harus disaring

doi: http://dx.doi.org/10.23960/aec.v5.i1.2020.p24-33

Anal.Environ.Chem. 
untuk menghilangkan partikel sampel sebelum analisis komponen yang diekstraksi. Skema peralatan MAE dapat dilihat pada Gambar 3.

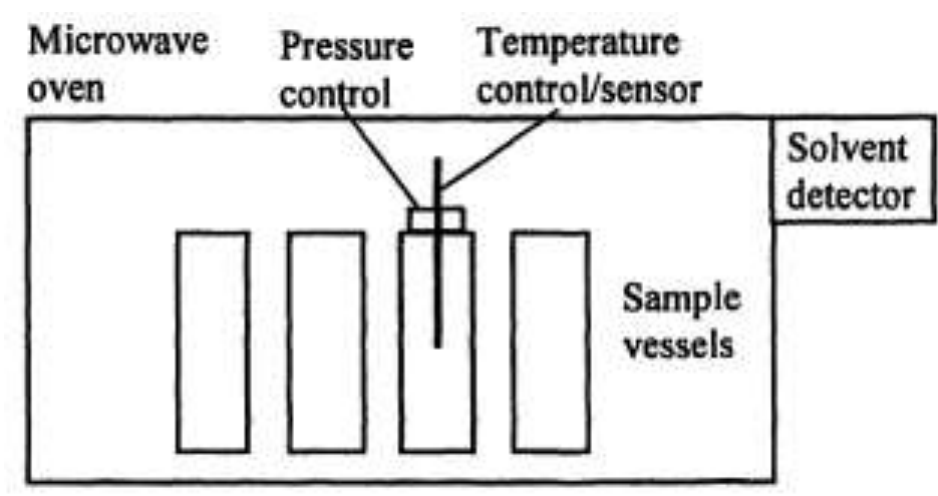

Gambar 3. Skema Sederhana Instrumen MAE

MAE adalah teknik yang lebih manual daripada Pressurized Liquid Extraction (PLE) karena dilakukan dalam mode batch. Meskipun demikian, banyak sampel dapat diproses secara bersamaan. Kelebihan lain dari MAE adalah bahwa pemanasan pelarut cepat, pelarut berjalan dari dalam sampel dan keluar sampel, dan kemampuan pemanasan tergantung pada sifat penyerap gelombang mikro. Pelarut polar seperti aseton akan menyerap energi gelombang mikro secara efisien, karena memiliki molekul dengan momen dipol permanen yang dapat berinteraksi dengan gelombang mikro. Pelarut non-polar seperti heksana tidak akan dipanaskan ketika terkena gelombang mikro, tetapi sebaliknya dapat digunakan dalam campuran dengan pelarut polar untuk mendapatkan sifat pemanasan yang diinginkan. Beberapa campuran pelarut umum yang telah digunakan dalam MAE adalah asetonitril/metanol, heksana/aseton, etilasetat/sikloheksana dan isooktana/aseton.

Aplikasi MAE dalam literatur mencakup misalnya ekstraksi capsaicinoid dari buah capsicum, PBDEs dari jaringan biologis laut, pestisida dari sayuran dan pigmen dari bubuk paprika (William et al. 2004). Secara umum, pengembangan metode dalam MAE melibatkan optimalisasi komposisi pelarut, volume pelarut, suhu ekstraksi dan waktu ekstraksi. Suhu campuran pelarut/sampel biasanya jauh di atas titik didih pelarut. Oleh karena itu, MAE memanfaatkan dengan cara yang sama seperti pada kekuatan pelarut PLE yang ditingkatkan dan difusi yang lebih cepat dari pelarut yang dipanaskan.

doi: http://dx.doi.org/10.23960/aec.v5.i1.2020.p24-33 Anal.Environ.Chem. 
Tsukui et al. (2014) juga melakukan ekstraksi minyak dari tiga belas macam kopi hijau berbeda (Coffea arabica L.) dengan menggunakan metode Microwave Assisted Extraction (MAE). Desain faktorial lengkap diterapkan pada MAE terkait dengan parameter waktu dan suhu, sehingga dihasilkan kerja yang optimum pada waktu 10 menit dan suhu $45^{\circ} \mathrm{C}$ untuk mengesktraksi minyak dari kopi hijau. Kuantifikasi kafestol dan kahweol diterpen yang ada dalam minyak kopi dianalisis menggunakan HPLC / UV. Kandungan minyak dan diterpen yang diperoleh dengan MAE untuk 13 sampel biji kopi hijau Arabika yang diperoleh di berbagai wilayah geografis Brasil ditunjukkan pada Tabel 1. Hasil yang diperoleh dari metode MAE sangat menarik dan memberikan lebih banyak keuntungan. Contoh yang baik adalah biji kopi AT1 (Tabel 1). Dalam penelitian tersebut ekstraksi dilakukan selama 10 menit menghasilkan 0,035 g diterpen. Manfaat lain yang penting dari MAE adalah hanya dibutuhkan sejumlah kecil pelarut, yakni 30mL, untuk melakukan prosedur ekstraksi. Sebagai perbandingan, metode Soxhlet setidaknnya menggunakan pelarut sebanyak $80 \mathrm{~mL}$ untuk 'merendam' sampel padat, lalu ditambah volume tambahan lain untuk benar-benar mengekstraksi minyak di bawah refluks, dan ini mencapai $110 \mathrm{~mL}$. Beberapa hilangnya pelarut karena penguapan juga harus dipertimbangkan.

Tabel 1. Hasil Minyak dan Diterpena dari 13 Biji Kopi Hijau Arabika Brazil

\begin{tabular}{ccc}
\hline Kopi & Hasil Minyak (g/kg biji kopi) & Diterpena $(\mathbf{g} / \mathbf{k g}$ biji kopi) \\
& & \\
\hline AT1 & $68.7 \pm 1.4(0.020)$ & $6.31 \pm 0.22(0.035)$ \\
AT2 & $59.7 \pm 1.7(0.028)$ & $4.53 \pm 0.06(0.014)$ \\
AT3 & $59.2 \pm 0.2(0.002)$ & $4.54 \pm 0.13(0.028)$ \\
AT4 & $58.6 \pm 2.0(0.034)$ & $5.95 \pm 0.12(0.020)$ \\
AT5 & $61.2 \pm 0.7(0.011)$ & $6.93 \pm 0.03(0.004)$ \\
AT6 & $70.4 \pm 1.2(0.016)$ & $7.73 \pm 0.20(0.026)$ \\
AT7 & $68.0 \pm 2.1(0.031)$ & $8.91 \pm 0.26(0.030)$ \\
AT8 & $67.8 \pm 1.3(0.019)$ & $7.69 \pm 0.20(0.026)$ \\
AT9 & $66.1 \pm 1.1(0.016)$ & $7.43 \pm 0.13(0.018)$ \\
AT10 & $65.1 \pm 1.2(0.019)$ & $7.28 \pm 0.13(0.018)$ \\
AT11 & $73.8 \pm 0.4(0.006)$ & $8.58 \pm 0.13(0.015)$ \\
AT12 & $72.2 \pm 0.2(0.003)$ & $7.82 \pm 0.24(0.030)$ \\
AT13 & $76.1 \pm 2.1(0.028)$ & $7.73 \pm 0.08(0.011)$ \\
\hline
\end{tabular}

doi: http://dx.doi.org/10.23960/aec.v5.i1.2020.p24-33 Anal.Environ.Chem. 
Berbagai konsentrasi untuk diterpenes cafestol dan kahweol dalam biji kopi hijau: 0,080,28 g/kg (Speer et al., 1999), 0,05-0,2 g/kg (Speer and Kölling-Speer, 2006), 8,7-9,7g/kg (Kitzberger et al., 2013) dilaporkan telah dihasilkan dari berbagai metode ekstraksi yang digunakan, dan dipengaruhi juga faktor variasi geografis, pertanian dan iklim yang mengganggu tanaman kopi. Pada penelitan ini, hasil diterpen dalam biji kopi hijau adalah 4,5-8,9 g/kg, di mana untuk minyak kopi hijau, hasil diterpen yang diperoleh adalah dari 75,8 hingga 131,0 g/kg dengan menggunakan metode Microwave Assisted Extraction (MAE).

\section{DAFTAR PUSTAKA}

Anwar, M., Kimia Hijau/Green Chemistry. 2015. Publikasi Ilmiah Pakan. Balai Penelitian Teknologi Bahan Alam, LIPI. http://bptba.lipi.go.id/bptba3.1/?u=blogsingle\&p=343\&lang=id). diakses pada tanggal 15 Januari 2016.

Boekschoten, M., Schouten, E.G, and Katan, M. 2004. Coffee Bean Extracts Rich and Poor in Kahweol both Give rise to Elevation of Liver Enzymes in Healthy Volunteers, Nutrition Journal, 3, $1-8$.

Ferrari, M., Ravera, F., De Angelis, E., Suggiliverani, F. and Navarini, L. 2010. Interfacial Properties of Coffee Oil. Colloids and Surfaces A: Physicochemical and Engineering Aspects. 365, $79-82$.

Juliasih, N.L.G.R., Yuan, L.C., Atsuta, Y., and Daimon, H. 2016. Development of Coupled Supercritical Fluid Extraction-High Performance Liquid Chromatography for Quinone Analysis in Activated Sludge. Separation Science and Technology, 51(3) , 439 - 446.

Kitzberger, C.S. G., Scholz M.B.S, Pereira, L.F.P., Vieira, L.G.E., Sera, T and Silva. J.B.G.D. 2013. Diterpenes in Green and Roasted Coffee of Coffee Arabica Cultivars Growing in the Sama edapho-climatic Conditions. Journal of Food Composition and Analysis, 30, 52 57.

Lam, L.K.T., Sparnins, V.L. and Watterberg, L.W. 1982. Isolation and Identification of Kahweol Palmitate and Cafestol Palmitate Active Constituents of Green Coffee Beans that Enhance Glutathione S-transferase Activity in the Mouse. Cancer Research, 42, 1193 - 1198.

Namiesnik, J. 2000. Trends in environmental analytics and monitoring in Crit. Rev. Anal. Chem. 30(2). 221-269.

Oliveira, P. M. A., Almeida, R.H., Oliveira N.A., Bostyn, S., Goncalves, C.B., and Oliveira, A.L. 2014. Enrichment of Diterpenes in Green Coffee Oil using Supercritical Fluid

doi: http://dx.doi.org/10.23960/aec.v5.i1.2020.p24-33

Anal.Environ.Chem. 
Extraction-Characterization and Comparison with Green Coffee Oil from Pressing. Journal of Supercritical Fluid, 95, $137-145$.

Pourmortazavi, S.M., Nasrabadi, M.R., Hajimirsadeghi, S.S. 2014. Supercritical Fluid Technology in Analytical Chemistry-Review. Current Analytical Chemistry, 10(1), 3-28.

Rinawati. 2017. Green Analytical Chemistry: Solid Phase Microextraction (SPME) dan Pressurized Fluid Extraction (PFE) untuk penentuan Polsiklik Aromatik Hidrokarbon (PAH). Analit: Analytical and Environmental Chemistry. 2(01). 63-71.

Speer, K. I., Strohschneider, S. and. Speer, K. 1999. Determination of Free Diterpenes in Green and Roasted Coffees. Journal of High Resolution Chromatography, 22. 43 - 46.

Speer, K. and Kölling-Speer, I. 2006. The Lipid Fraction of the Coffee Bean. Brazilian Journal of Plant Physiology, 18, $201-216$.

Tsukui, A., Junior, H.M.S., Oigman, S.S., . de Souza, R.O.M.A, . Bizzo, H.R., and Rezende, C.M. 2014. Microwave-Assisted Extraction of Green Coffee Oil and Quantification of Diterpenes by HPLC. Food Chemistry. 164, 266 - 271.

Turner, C. 2006. Modern Extraction Technique. American Chemical Society. Washington D.C.

Williams, O. J., Raghavan, G. S. V., Orsat, V., and Dai, J. 2004. Microwave-Assisted Extraction of Capsaicinoids from Capsicum Fruit. Food Biochem. 28. 113-122.

doi: http://dx.doi.org/10.23960/aec.v5.i1.2020.p24-33

Anal.Environ.Chem. 